\title{
Bacillus subtilis BS-2 AND PEPPERMINT OIL AS BIOCONTROL AGENTS AGAINST Botrytis cinerea
}

\author{
Bacillus subtilis BS-2 ORAZ OLEJEK MIETTOWY \\ JAKO CZYNNIKI BIOKONTROLI WOBEC Botrytis cinerea
}

\begin{abstract}
The purpose of this study was to assess the activity of Bacillus subtilis BS-2 and peppermint oil against Botrytis cinerea. In this study parameters such as the age and the density of the bacterial culture and the incubation temperature were taken into consideration. Furthermore, the cellulolytic activity of the bacterium was determined. The effect of peppermint oil was evaluated at a concentration range of 0.5-4.0\%. The research was conducted with a dual culture plate method. The influence of $B$. subtilis BS-2 and peppermint oil on the growth of $B$. cinerea was evaluated based on the growth rate index. It was noted that the bacterial culture occurred at an initial density of $O D_{560}=1.0$, cultivated at $30{ }^{\circ} \mathrm{C}$ for 48 hours demonstrated the strongest antagonistic effect (57.07\% inhibition). Furthermore, it was observed that the highest cellulolytic activity occurred on the bacteria incubated for 48 hours at $37{ }^{\circ} \mathrm{C}$. The effect of mint oil, at the lowest concentration of $0.5-1.0 \%$, was much weaker on bacterial activity (1.1-12.1\% inhibition). The highest concentration (4.0\%) of mint oil caused the maximum inhibition (31.9\%) of the mycelial growth. B. subtilis BS-2 may be environmental-friendly alternatives for protecting plants against B. cinerea
\end{abstract}

Keywords: Bacillus subtilis BS-2, CMCase activity, peppermint oil, antifungal activity, Botrytis cinerea

\section{Introduction}

Grey mould, caused by the fungus $B$. cinerea, is one of the most significant agricultural phytopathogens that can infect plants throughout all stages of their growth. For example, in cold and damp weather conditions it can affect strawberry plants, attacking the flowers, leaves, and mature fruit $[1,2]$. $B$. cinerea produces large amounts of conidia that are widespread in the air and can be readily transported by wind over long distances. It also produces long-lived structures called sclerotia which are able to survive in the absence of a host plant [3]. For this reason, B. cinerea may cause serious pre- and post-harvest diseases and can be one of the most difficult plant diseases to prevent or control [4-6]. Control of grey mould disease is usually carried out by the application of chemical fungicides, which are generally not effective and lead to contamination of the environment, accumulation of toxic residues in fruits, and can cause toxic effects on human health [2, 7, 8]. Several

\footnotetext{
${ }^{1}$ Institute of Biotechnology, University of Opole, ul. kard. B. Kominka 6, 45-035 Opole, Poland, phone +48774016056

${ }^{2}$ Institute of Medicine, University of Opole, ul. Oleska 48, 45-052 Opole, Poland, phone +48 774527242

*Corresponding author: kgrata@uni.opole.pl
} 
studies have shown that the best alternatives with the potential to control Botrytis cinerea include filamentous fungi (Trichoderma sp., Gliocladium sp.), yeast (Pichia sp., Candida sp.), bacteria (Pseudomonas sp., Bacillus sp.), and certain essential oils [9-11]. Several mechanisms have been indicated as responsible for their antagonistic activity, including: mycoparasitism [9], secretion of bioactive compounds (trichozianins A1 and B1 from T. harzianum, gliotoxin from G. virens, pyrolnitrin from P. cepacia, and flagelin-like protein from $B$. subtilis) [9, 12], competition for space and nutrients, promotion of plant growth (the growth of plant seedlings, increased the biomass seedlings) [2, 13] and induction of systemic resistance (ISR) [14]. These microorganisms can cause inhibition of mycelium growth, morphological changes of mycelium, weakness or inhibition of spore germination, and inhibition of hyphal elongation [2, 4, 11].

The search for antagonists for plant protection has intensified in recent years. There have been many studies on the effectiveness and potential of various bacteria from the genera Bacillus and Pseudomonas or essential oils from the Lamiaceae family against various fungal pathogens e.g. Fusarium sp., Penicillium sp., Rhizoctonia solani, Alternaria sp., Botrytis cinerea [15-19]. The Bacillus genus, particularly B. subtilis and the closely related $B$. amyloliquefaciens species, are being widely researched for their potential to function as biocontrol agents. Their beneficial attributes for plant protection and growth promotion include the synthesis of broad spectrum active metabolites and the ability to adapt in various environmental conditions. In contrast, essential oils contain a range of biologically active components, most of which exhibit different effects on the pathogens e.g. inhibiting the growth of mycelium and spore germination by membrane disruption, inhibiting the action of enzymes and/or causing their complete inactivation. Thus, biological methods of protection against Botrytis sp., such as using microorganisms or their metabolites and plant extracts or essential oils, offer an effective alternative or complement to the use of conventional disease control methods $[2,3,9,14]$.

The aim of this study was to assess the suppressing effect of Bacillus subtilis BS-2 and peppermint oil (Mentha piperita L.) on the mycelium growth of Botrytis cinerea isolated from strawberries.

\section{Materials and methods}

\section{Preparation of microbial cultures}

The Bacillus subtilis strain, encoded as BS-2, was cultured in a broth medium on a rotary shaker at $100 \mathrm{rpm}$ at $35^{\circ} \mathrm{C}$ for $48 \mathrm{~h}$. It was then inoculated into a flask containing both the nutrient broth and $\mathrm{CMC}$ liquid medium containing $\left(\mathrm{g} / \mathrm{dm}^{3}\right) \mathrm{KH}_{2} \mathrm{PO}_{4} 1.0$, $\mathrm{MgSO}_{4} \cdot 7 \mathrm{H}_{2} \mathrm{O} 0.5, \mathrm{NaCl} 0.5, \mathrm{FeSO}_{4} \cdot 7 \mathrm{H}_{2} \mathrm{O} 0.01, \mathrm{MnSO}_{4} \cdot \mathrm{H}_{2} \mathrm{O} 0.01, \mathrm{NH}_{4} \mathrm{NO}_{3} 0.3, \mathrm{CMC} 10.0$ [20], with bacterial cultures at a density of $O D_{560}=1.0\left(1.5 \cdot 10^{6} \mathrm{CFU} / \mathrm{cm}^{3}\right)$ and $O D_{560}=2.0$ $\left(1.8 \cdot 10^{8} \mathrm{CFU} / \mathrm{cm}^{3}\right)$. Then these cultures were incubated at 30 and $37{ }^{\circ} \mathrm{C}$ for different lengths of time in order to attain 6, 24 and 48-hour cultures. After each time period, the cultures were centrifuged at $10000 \mathrm{rpm}$ for $20 \mathrm{~min}$ at $4{ }^{\circ} \mathrm{C}$. The cell-free supernatants $(\mathrm{CFs})$ containing the metabolite and the crude enzyme were analyzed in order to detect the degree of antifungal and carboxymethyl cellulase activities. The $B$. cinerea strain isolated from strawberries was cultivated on a PDA medium at $25^{\circ} \mathrm{C}$ for 7 days. 


\section{Determination of the antagonistic activity of $B$. subtilis BS-2 and peppermint oil against $B$. cinerea}

The fungistatic activity of $B$. subtilis and peppermint oil (Mentha piperita L.) was determined using the culture-plate method on potato dextrose (PDA) medium. The supernatants and the essential oil were spread thoroughly all over the surface of PDA plates. Fungal mycelial-discs $(8.0 \mathrm{~mm}$ in diameter) obtained from the growing cultures of test fungal isolate were placed at the centre of the medium inoculated with the supernatants. The control plates contained only $B$. cinerea cultures and aseptic broth medium in place of the supernatants. In order to evaluate the effect of the peppermint oil on the mycelial growth, the following concentrations of EO were used: - 0.5, 1.0, 2.0, $4.0 \%$. Initially, in order to enhance the essential oil solubility, the oil was dissolved with $0.5 \%$ dimethyl sulfoxide (DMSO). In the control tests, the essential oil was replaced with $0.5 \%$ DMSO solution and inoculated in the same manner as in the tests evaluating the antifungal activity of $B$. subtilis BS-2. All plates were incubated at $25 \pm 2{ }^{\circ} \mathrm{C}$ for 8 days and the fungal linear growth was measured every 1-2 days until the mycelium of $B$. cinerea in the control plate reached the edge of the plate. The experiments were performed in four replicates, where one repeat was represented by one plate containing the growth medium with one mycelia disc. The influence of metabolites produced by B. subtilis BS-2 and essential oil on the growth of this fungus was determined based on the growth rate index $(G R I)$ [21].

$$
G R I=\frac{A}{D}+\frac{b_{1}}{d_{1}}+\ldots+\frac{b_{x}}{d_{x}}
$$

where: $A$ - mean value of colony diameter measurements $[\mathrm{mm}], D$ - duration of the experiment [days], $b_{1} \ldots b_{x}$ - colony diameter increase since last measurement [mm], $d_{1} \ldots d_{x}$ - number of days since the last measurement.

The inhibition of fungal growth was evaluated as the percentage reduction of the growth rate index of the treated plate versus the growth rate index of the control plate.

\section{Carboxymethyl cellulase activity assay}

The activity of carboxymethylcellulase (CMCase) was determined by the colorimetric method measuring the release of reducing sugars by the 3,5-dinitrosalicylic acid (DNS) [22]. The enzyme assay was conducted by incubating the reaction mixture containing the suitable CFs and $1 \%(\mathrm{w} / \mathrm{v})$ final concentration of CMC, prepared in sodium acetate buffer $(\mathrm{pH}=5.0)$. After incubation for $30 \mathrm{~min}$ at $50{ }^{\circ} \mathrm{C}$, the DNS reagent was added to the above mixture to stop the reaction. The control for the enzyme assay was run simultaneously. The colour of the reaction mixture was developed in a boiling water bath for 10 minutes. After cooling, the absorbance was measured at $540 \mathrm{~nm}$. Standard curves were prepared for D-glucose. One unit of CMCase activity was determined as the amount of enzyme that catalyzes the release of $1 \mu \mathrm{mol}$ of glucose per $\mathrm{cm}^{3}$, per minute under the assay conditions $\left[\mathrm{U} / \mathrm{cm}^{3}\right]$.

\section{Determination of protein content and specific enzyme activity}

The crude protein concentration was determined according to the Lowry method [23]. Bovine serum albumin (BSA) was used as the standard to calculate the specific enzyme activity [U/mg protein]. The hydrolytic ability of the crude enzyme against $0.5 \% \mathrm{CMC}$ was determined to evaluate substrate specificity. 


\section{Statistical analysis}

All experiments were conducted in four replicates. The data are expressed as the mean standard deviation. Differences between the treatments and analyzed parameters were performed using two-way analysis of variance with a Tukey's composition test (statistic program MegaStat, Two-factor ANOVA). Significant differences were determined with $99 \%$ confidence intervals $(p \leq 0.01)$.

\section{Results and discussion}

The studies show that bacterial density, culturing time, and the temperature of cultivation all had a significant impact on the growth of mycelium and the degree of inhibition. The antifungal activity of various supernatants of $B$. subtilis BS-2 on the growth of $B$. cinerea on PDA medium is presented in Table 1 and Figure 1 . In these tests, we observed that in the presence of supernatants the mycelium grew slower and was morphologically altered compared to the mycelium in the control tests. Statistical differences were found $(p \leq 0.01)$ between the control and other supernatants (Table 1).

Effects of B. subtilis BS-2 on the growth rate index (GRI) of B. cinerea

\begin{tabular}{|c|c|c|c|c|}
\hline \multirow{2}{*}{ Treatment $\left(^{*}\right)$} & \multicolumn{3}{|c|}{ Culturing time [hours] } & \multirow{2}{*}{ Mean } \\
\cline { 2 - 5 } & $\mathbf{6}$ & $\mathbf{2 4}$ & $\mathbf{4 8}$ & $77.60^{\mathrm{A}}$ \\
\hline Control & $77.60 \pm 0.26^{\mathrm{A}}$ & $77.60 \pm 0.26^{\mathrm{A}}$ & $77.60 \pm 0.26^{\mathrm{A}}$ & $41.77^{\mathrm{C}}$ \\
$O D 1.0 / T 30^{\circ} \mathrm{C}$ & $51.5 \pm 1.5^{\mathrm{B}}$ & $40.5 \pm 1.69^{\mathrm{C}}$ & $33.31 \pm 0.82^{\mathrm{D}}$ & $44.33^{\mathrm{B}}$ \\
$O D 2.0 / T 30^{\circ} \mathrm{C}$ & $50.6 \pm 1.1^{\mathrm{B}}$ & $40.18 \pm 0.16^{\mathrm{C}}$ & $42.2 \pm 1.7^{\mathrm{C}}$ & $45.22^{\mathrm{B}}$ \\
$O D 1.0 / T 37^{\circ} \mathrm{C}$ & $41.2 \pm 1.2^{\mathrm{C}}$ & $48.1 \pm 1.4^{\mathrm{B}}$ & $46.35 \pm 0.67^{\mathrm{B}}$ & $41.27^{\mathrm{C}}$ \\
$O D 2.0 / T 37^{\circ} \mathrm{C}$ & $40.0 \pm 1.9^{\mathrm{C}}$ & $37.1 \pm 2.0^{\mathrm{D}}$ & $46.7 \pm 1.97^{\mathrm{B}}$ & 50.04 \\
\hline Mean & $52.18^{\mathrm{A}}$ & $48.70^{\mathrm{B}}$ & $49.23^{\mathrm{B}}$ & 50.04 \\
\hline
\end{tabular}

Values represent mean \pm standard devition of four replicates; values with the different capital letters are significant at $p<0.01 ;\left(^{*}\right) O D$ - optical density; $T$ - temperature

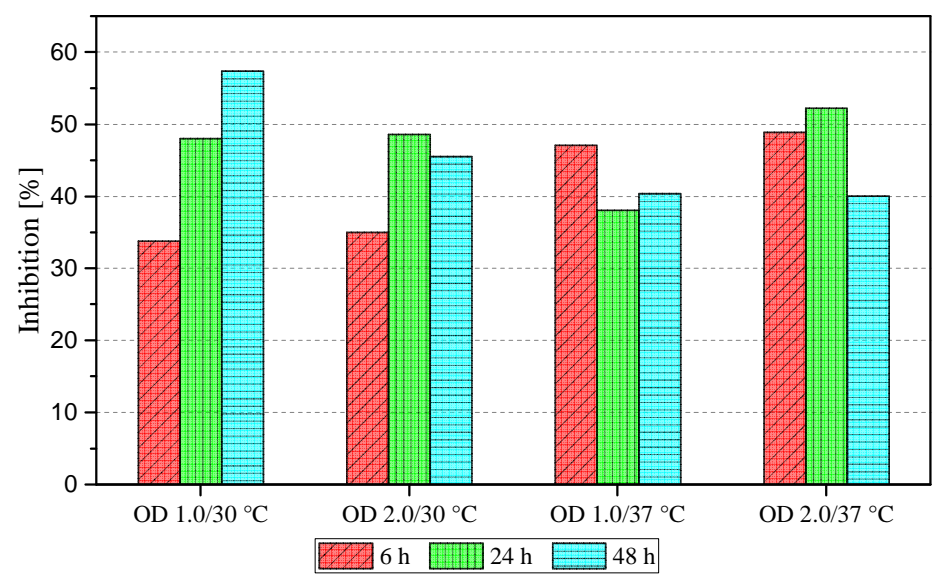

Fig. 1. Effects of B. subtilis BS-2 on mycelial growth of B. cinerea; OD - optical density; $30,37{ }^{\circ} \mathrm{C}$ incubation temperature; $6 \mathrm{~h}, 24 \mathrm{~h}, 48 \mathrm{~h}$ - time of the bacterial culture 
The strongest antifungal activity in all supernatants against $B$. cinerea was observed in the $48 \mathrm{~h}$ culture at initial $O D_{560}=1.0$ incubated at $30{ }^{\circ} \mathrm{C}$ with a growth rate index $(G R I)$ of 33.31. Close results were observed for the antifungal activity of supernatants in the 24-hour and 6-hour cultures at initial $O D_{560}=2.0$ incubated at $37^{\circ} \mathrm{C}$, with a $G R I$ of 37.15 and 40.02 , respectively (Table 1). The inhibitory effect of $B$. cinerea in the presence of the above-mentioned supernatant reached the values 57.07, 52.13 and $48.43 \%$, respectively (Fig. 1).

It was observed that in order to attain a similar antifungal effect, the higher density of bacterial culture $(O D=2.0)$ incubated at the higher temperature $\left(37^{\circ} \mathrm{C}\right)$ needed a shorter incubation time $(6 \mathrm{~h}, 24 \mathrm{~h})$ than the lower density of bacterial culture $\left(O D_{560}=1.0\right)$ incubated at the lower temperature $\left(30{ }^{\circ} \mathrm{C}\right.$ ) (Fig. 1). The high antifungal activity of B. subtilis BS-2 observed may be due to its ability to produce cellulolytic enzymes, peptides, and another metabolites which can play an important role in limiting the growth of phytopathogenic fungi.

Production of CMCase from cell-free culture of B. subtilis BS-2

\begin{tabular}{|c|c|c|c|c|}
\hline \multirow{2}{*}{ Treatment $\left(^{*}\right)$} & \multicolumn{4}{|c|}{ CMCase activity [U/. $\left.{ }^{3}\right]$} \\
\cline { 2 - 5 } & $\mathbf{6 ~ h o u r}$ & $\mathbf{2 4}$ hour & $\mathbf{4 8 ~ h o u r}$ & Mean \\
\hline$O D 1.0 / T 30^{\circ} \mathrm{C}$ & $0.020 \pm 0.0004$ & $0.022 \pm 0.0006$ & $0.023 \pm 0.0007$ & $0.021^{\mathrm{C}}$ \\
$O D 2.0 / T 30^{\circ} \mathrm{C}$ & $0.019 \pm 0.0006$ & $0.021 \pm 0.0005$ & $0.021 \pm 0.0004$ & $0.020^{\mathrm{C}}$ \\
$O D 1.0 / T 37^{\circ} \mathrm{C}$ & $0.023 \pm 0.0005$ & $0.030 \pm 0.0004$ & $0.035 \pm 0.0003$ & $0.029^{\mathrm{A}}$ \\
$O D 2.0 / T 37^{\circ} \mathrm{C}$ & $0.021 \pm 0.0004$ & $0.023 \pm 0.0006$ & $0.029 \pm 0.0003$ & $0.024^{\mathrm{B}}$ \\
\hline Mean & $0.021^{\mathrm{C}}$ & $0.024^{\mathrm{B}}$ & $0.027^{\mathrm{A}}$ & \\
\hline
\end{tabular}

Values represent mean \pm standard deviation of four replicates; values with the different capital letters are significant at $p<0.01 ;\left(^{*}\right) O D$ - optical density; $T$ - temperature

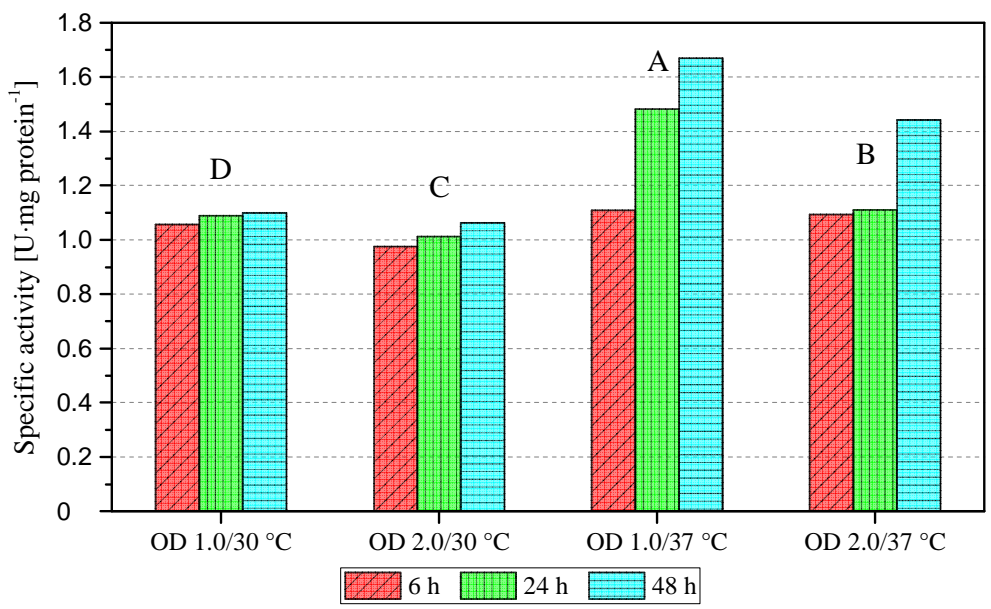

Fig. 2. Specific activity (CMCase) of B. subtilis BS-2 grown in CMC medium; Values with the different capital letters are significant at $p<0.01 ; O D$ - optical density; $30{ }^{\circ} \mathrm{C}, 37{ }^{\circ} \mathrm{C}$ - incubation temperature; $6 \mathrm{~h}, 24 \mathrm{~h}, 48 \mathrm{~h}$ - time of the bacterial culture

In this study, the Bacillus subtilis B-2 was able to produce cellulolytic enzymes. The CMCase activity and specific enzyme activity were recorded based on the $\mathrm{U} / \mathrm{cm}^{3}$ and 
U/mg protein, respectively (data analysis shown in Table 2, Fig. 2). The temperature had the greatest influence on the CMCase production by the BS-2 strain. The highest values were obtained when the strain was grown at $37{ }^{\circ} \mathrm{C}$. Furthermore, an increase of activity was found in supernatants obtained from the bacterial culture at initial density $O D_{560}=1.0$. The level of CMCase activity ranged from $0.023 \mathrm{U} / \mathrm{cm}^{3}$ (for 6 hour of CFs) to $0.035 \mathrm{U} / \mathrm{cm}^{3}$ (for 48 hour of CFs) and from $0.83 \mathrm{U} / \mathrm{mg}$ protein to $1.31 \mathrm{U} / \mathrm{mg}$ protein (specific enzyme activity). Also, with the increase of incubation time of the bacterial culture from 6 o $48 \mathrm{~h}$, there was a slight increase in CMCase activity and the specific activity was recorded (Table 2, Fig. 2).

Among all of the variants the highest level of activity up to $0.035 \mathrm{U} / \mathrm{cm}^{3}$ (CMCase) and up to $1.31 \mathrm{U} / \mathrm{mg}$ protein was obtained for B. subtilis BS-2 culture at initial density 1.0 incubated at $37{ }^{\circ} \mathrm{C}$ for $48 \mathrm{~h}$. No significant relationship between the antagonistic activity of B. subtilis BS-2 strain and the level of CMCase production was observed. The cell-free culture at $O D_{560}=2.0$ incubated at $37{ }^{\circ} \mathrm{C}$, which recorded the highest antifungal activity, exhibited the lowest CMCase activity (Table 2, Fig. 2).

Compared to the bacterial activity, the effect of Mentha piperita L. on mycelial growth was much weaker. It was observed that with the increase of peppermint oil concentration there was a deceleration of B. cinerea mycelial growth (Fig. 3).

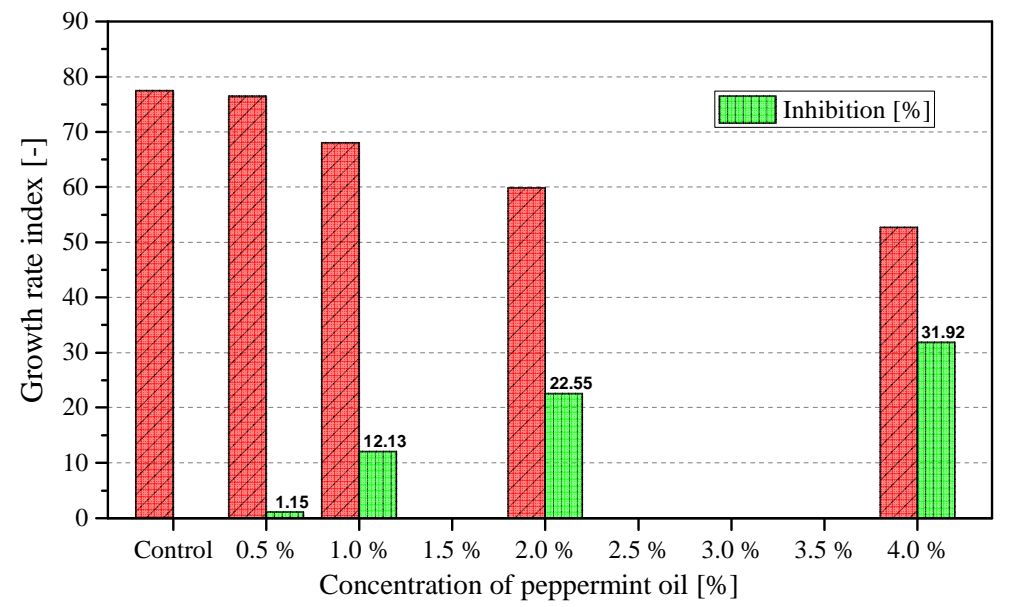

Fig. 3. Mycelial growth and inhibition of $B$. cinerea by peppermint oils at different concentrations; Values with the different capital letters are significant at $p<0.01$; $0.5,1.0,2.0,4.0 \%$ - concentrations of peppermint oils

The growth rate index of mycelium was between 76.71 (at $0.5 \%$ essential oil) and 52.83 (at $4.0 \%$ essential oil) compared to the control 77.6. The peppermint oil reached maximum efficiency only at the highest concentration $(4.0 \%)$, where the mycelial growth of $B$. cinerea was reduced by $31.9 \%$. The lowest concentration of the peppermint oil $(0.5 \%$ ) caused the least inhibition of the mycelial growth at only $1.15 \%$ (Fig. 3).

The results obtained from our study are in agreement with the results of other authors who showed in vitro suppression of the growth of the $B$. cinerea in interaction with bacteria of the genus Bacillus [12, 24]. B. subtilis S1-0210 was found to be effective on the fungus and inhibited the mycelial growth of $B$. cinerea in kiwi fruit at about $66 \%$ and in 
strawberries at about $80 \%$ [25]. B. amyloliquefaciens IMAUB1034 proved to have even greater inhibitory properties against Botrytis sp. $(95.3 \%)$ due to the synthesis of surfactin [26]. Shternshis et al. [2] tested strains of Bacillus under laboratory conditions and found they suppressed the growth of the phytopathogenic fungus $B$. cinerea in the range of $70 \%$ (for B. licheniformis) to $100 \%$ (for B. subtilis, B. amyloliquefaciens). The inhibitory effect depended on the concentration of the tested bacterial suspension and was achieved at the highest concentration $\left(10^{6} \mathrm{CFU} / \mathrm{cm}^{3}\right)$. Research undertaken by Wang et al. [27] showed that the inhibitory effect of $B$. subtilis EB-28 on mycelial growth of Botrytis cinerea reached about $70 \%$, similar to that observed by Torue et al. [18] as well as in this present study. Such a low mycelial growth could be related to the production of individual lipopeptides in the various bacterial cell growth phases [18]. Numerous scientific studies have reported that some Bacillus strains are capable of producing antibiotics with antifungal properties. These include the cyclic lipopeptides such as surfactin, subtilin, fengicyn [18, 28-30], and kanosamine [14, 31]. Furthermore these compounds were found capable of degrading the cell structure and increasing the permeability of the cell fungi. Some studies have shown that fengycins are synthesized by B. subtilis GA1 in the late logarithmic or early stationary phase [18], in contrast with surfactins which are produced during exponential growth, and iturins which are produced in the later stationary phase [32]. Recent evidence shows that Bacillus strains are capable also of producing volatile compounds with an antifungal nature against the plant pathogen [14, 33, 34]. Chen et al. [4] confirm this in their results, identifying 14 components produced by B. subtilis JA (including, among others, 2-ethyl-hexanol, ammonium acetate, tetramethyl-pyrazine). They show that the spore germination and the germ tube elongation of $B$. cinerea were significantly inhibited. Liu et al. [33] reported that most of $B$. cinerea spores exposed to the volatile compounds of the bacteria were cracked and the inclusions were browned. This may have been related to the water solubility of the volatile compounds diffused and dissolved in the culture medium.

Moreover, several Bacillus sp. strains are able to produce bioactive mycolytic enzymes, including proteases [34-36], $\beta$-1,3-glucanase, cellulose and chitinase [14, 34, 37], that inhibit the growth of phytopathogenic fungi through the lysis of cell walls. Several authors have reported on the effect of different growth parameters (the inoculum concentration, temperature, growth time, $\mathrm{pH}$ value) on carboxymethylcellulase activity of Bacillus sp. The extremely low level of CMCase activity was detected in the culture supernatant at early logarithmic phase of growth presumably due to the low density of cells and a rapid increase of enzyme level during log phase [38-41]. In this present study the maximum enzyme was found when the cultures were incubated at $37{ }^{\circ} \mathrm{C}$. Similar observations have also been made by other researchers. In this study, the maximum cellulolytic efficiency was obtained at $40{ }^{\circ} \mathrm{C}$ by B. subtilis, B. circulans [40] and by $B$. brevis [42]. These findings are congruous with Dias et al. [43] who observed an increase in carboxymethylcellulase activity of Bacillus C1AC55.07 with an increase in temperature.

Several studies on the use of essential oils as fungicides have been published, and have suggested that natural plants could be used instead of synthetic fungicides or as fumigants $[16,44]$. Essential oils from plants of the Lamiaceae family, or some of their constituents, were found to possess antifungal properties against the frequently tested phytopathogenic fungi [45]. Bouchra et al. [16] reported that essential oil from $M$. piperita was not effective at doses lower than $250 \mathrm{ppm}$, whereas $M$. pulegium inhibited the mycelial growth of B. cinerea by $4.1 \%(50 \mathrm{ppm})$ to $58.5 \%(250 \mathrm{ppm})$. Sesan et al. [17] observed the greatest 
inhibition of mycelial growth and the sporulation of $B$. cinerea in the blackcurrant, ranging from 37.5 to $100 \%$ (in vitro) and up to $70 \%$ (in vivo). Among Mentha species, M. pulegium was shown to be the most potent in comparison to $M$. spicata. This study found that $100 \%$ inhibition of $B$. cinerea growth occurred at concentrations above $350 \mathrm{ppm}$ for $M$. spicata and $100 \mathrm{ppm}$ for $M$. pulegium. Below these concentrations, essential oil efficacy ranged from 19.9 to $93.58 \%$ and amounted to $45.6 \%$, respectively [46]. Multiple factors play an important role in determining antifungal activity including the origin of the plant and the conditions of its cultivation as well as its composition, and the structure and the amount of essential oil. Many scientists have confirmed that there is a relationship between the chemical structure of the most abundant compounds in the essential oils and antimicrobial activity [16, 45-47]. Mentha piperita L. and other Mentha species essential oils mainly contain menthol, menthon, carvone, and methyl acetate in different concentrations [16, 48, 49]. Earlier investigations have shown differences in antifungal activities of various mint oils as a result of the different percentages of these components. The inhibitory effect of this oil can be explained by a high content of carvone and menthol, which possess very strong fungistatic and fungicidal activities. On the other hand, a lower efficacy of this essential oil may be due to a high content of methyl acetate which causes a decrease of antifungal properties [44, 50-53]. Other studies suggest that menthol alone was found to be the compound responsible for the antifungal properties of peppermint oil, whereas menthon alone did not show any effect at all on the concentrations [54]. The chemical composition of the oil depends largely on plant cultivation. The content of the individual components may be affected by the origin of the plant, its age, and cultivation conditions, among other factors [50].

\section{Conclusions}

Among the biological agents tested, the supernatants obtained from Bacillus subtilis BS-2 were found to be more effective to a higher degree in the suppression of mycelial growth than peppermint oil. The mycelial growth was most inhibited by the $48 \mathrm{~h}$ bacterial culture at initial $O D_{560}=1.0$ incubated at $30{ }^{\circ} \mathrm{C}$ (57.07\% maximum inhibition). Furthermore, the highest cellulolytic activity was demonstrated by the bacteria incubated for 48 hours at $37{ }^{\circ} \mathrm{C}$. In contrast, the peppermint oil (Mentha piperita L.) had much less of an impact on the linear mycelial growth of $B$. cinerea. Use of the highest dose of oil $(4 \%)$ reduced the linear growth of mycelium by $31.9 \%$. Therefore, this strain of B. subtilis BS-2 may be an environmentally friendly agent for plant protection against Botrytis cinerea.

\section{References}

[1] El-Ghanam AA, Farfour SA, Ragab SS. Bio-suppression of strawberry fruit rot disease caused by Botrytis cinerea. J Plant Pathol Microbiol. 2015;S3:005. DOI: 10.4172/2157-7471.S3-005.

[2] Shternshis MV, Belyaev AA, Shpatova TV, Lelyak AA. Influence of Bacillus spp. on strawberry gray mold causing agent and host plant resistance to disease. Contemp Prob Ecol. 2015;8:390-396. DOI: $10.1134 /$ S1995425515030130.

[3] Ongouya Mouekouba LD, Zhang ZZ, Olajide EK, Wang Ai-Jie, Wang Ao-Xue. Biological control of Botrytis cinerea in tomato leaves. IPCBEE. 2013;60:64-68. DOI: 10.7763/IPCBEE.

[4] Chen H, Xiao X, Wang J, Wu L, Zheng Z, Yu Z. Antagonistic effects of volatiles generated by Bacillus subtilis on spore germination and hyphal growth of the plant pathogen, Botrytis cinerea. Biotechnol Lett. 2008;30:919-923. DOI: 10.1007/s10529-007-9626-9.

[5] Williamson B, Tudzynski B, Tudzynski P, Kan JAL. Botrytis cinerea: The cause of grey mould disease, Mol Plant Pathol. 2007;8:561-580. DOI: 10.1111/J.1364-3703.2007.00417.X. 
[6] Zhang H, Wang L, Dong Y, Jiang S, Cao J, Meng R. Postharvest biological control of gray mold decay of strawberry with Rhodotorula glutinis. Biol Control. 2007;40:287-292. DOI: 10.1016/j.ijfoodmicro.2008.05.018

[7] Essghaier B, Fardeau ML, Cayol JL, Hajlaoui MR, Boudabous A, Jijakli H, et al. Biological control of grey mould in strawberry fruits by halophilic bacteria. J Appl Microbiol. 2009;106:833-846. DOI: 10.1111/j.1365-2672.2008.04053.x.

[8] Kowalska J. Effects of Trichoderma asperellum [T1] on Botrytis cinerea [PERS.: FR.], growth and yield of organic strawberry. Acta Sci Pol Hortorum Cultus. 2011;10:107-114. http://hortorumcultus.actapol.net/pub/10_4_107.pdf.

[9] Elad Y, Stewart A. Microbial control of Botrytis spp. Chapter 13. In: Elad Y, Williamson B, Tudzynski P, Delen N. editors. Botrytis: Biology, Pathology and Control. Dordrecht: Springer; 2007: 223-241. ISBN 9781402026263. DOI: 10.1007/978-1-4020-2626-3.

[10] Hernández-León R, Rojas-Solís D, Contreras-Pérez M, Orozco-Mosqueda MC, Macías-Rodríguez LI, Cruz $\mathrm{HR}$, et al. Characterization of the antifungal and plant growth-promoting effects of diffusible and volatile organic compounds produced by Pseudomonas fluorescens strains. Biol Control. 2015;81:83-92. DOI: 10.1016/j.biocontrol.2014.11.011.

[11] Jacometti MA, Wratten SD, Walter M. Review: Alternatives to synthetic fungicides for Botrytis cinerea management in vineyards. Aust J Grape Wine R. 2010:16:154-172. DOI: 10.1111/j.1755-0238.2009.0067.x.

[12] Ren JJ, Shi GL, Wang XQ, Liu JG, Wang YN. Identification and characterization of a novel Bacillus subtilis strain with potent antifungal activity of a flagellin-like protein. World J Microb Biot. 2013;29:2343-2352. DOI: $10.1007 / \mathrm{s} 11274-013-1401-6$.

[13] Zongzheng Y, Xin L, Zhong L, Jinzhao P, Jin Q, Wenyan Y. Effect of Bacillus Subtilis SY1 on antifungal activity and plant growth. Int J Agric Biol Eng. 2009;2:55-61. DOI: 10.3965/j.issn.1934-6344.2009.04.055-061.

[14] Alina SO, Constantiniscu F, Petruta CC. Biodiversity of Bacillus subtilis group and beneficial traits of Bacillus species useful in plant protection. Rom Biotech Lett. 2015;20:10737-10750. http://www.rombio.eu/vol20nr5/01\%20SICUIA\%20OANA\%20ALINA.pdf.

[15] Behdani M, Pooyan M, Abbasi S. Evaluation of antifungal activity of some medicinal plants essential oils against Botrytis cinerea, causal agent of postharvest apple rot, in vitro. Intl J Agri Crop Sci. 2012;4:1012-1016. https://www.researchgate.net/publication/292586844_Evaluation_of_antifungal_ activity_of_some_medicinal_plants_essential_oils_against_Botrytis_cinerea_causal_agent_of_postharvest_a pple_rot_in_vitro.

[16] Bouchra C, Mohamed A, Hassani Mina I, Hmamouchi M. Antifungal activity of essential oils from several medicinal plants against four postharvest citrus pathogens. Phytopathol. Mediterr. 2003;42:251-256. http://www.fupress.net/index.php/pm/article/view/1711/1646.

[17] Şesan TE, Enache E, Iacomi BM, Oprea M, Oancea F, Iacomi C. Antifungal activity of some plant extracts against Botrytis cinerea Pers. in the blackcurrant crop (Ribes nigrum L.). Acta Sci Pol Hortorum Cultus. 2015;14:29-43. http://www.acta.media.pl/pl/full/7/2015/000070201500014000010002900043.pdf.

[18] Toure Y, Ongena M, Jacques P, Guiro A, Thonar P. Role of lipopeptides produced by Bacillus subtilis GA1 in the reduction of grey mould disease caused by Botrytis cinerea on apple. $\mathrm{J}$ Appl Microbiol. 2004;96:1151-1160. DOI: 10.1111/j.1365-2672.2004.02252.x.

[19] Nabrdalik M, Moliszewska E, Wierzba S. Importance of endophytic strains Pantoea agglomerans in the biological control of Rhizoctonia solani. Ecol Chem Eng S. 2018;25:331-342. DOI: 10.1515/eces-2018-0023.

[20] Ariffin H, Abdullah N, Umi Kalsom MS, Shirai Y, Hassan MA. Production and characterisation of cellulase by Bacillus pumilus EB3. Int J Eng Technol. 2006;3:47-53. https://pdfs.semanticscholar.org/2ddf/2067a5aba34de9ded53aff23439854e0040d.pdf.

[21] Janda K. Lipolityc activity and radial daily growth rate changes during incubation of Thermomyces lanugonosus on natural and synthetic fatty substrates. Rocz Panstw Zakl Hig. 2005;56:347-353. https://www.researchgate.net/publication/7168868_Lipolytic_activity_and_radial_daily_growth_rate_chang es_during_incubation_of_thermomyces_lanuginosus_on_natural_and_synthetic_fatty_substrates.

[22] Miller GL. Use of dinitrosalicylic acid reagent for determination of reducing sugar. Anal Chem. 1959;31:426-428. DOI: 10.1021/ac60147a030.

[23] Lowry $\mathrm{OH}$, Rosebrough NJ, Farr AL, Randall RJ. Protein measurement with the Folin phenol reagent. J Biol Chem. 1951;19:265-275. http://www.jbc.org/content/193/1/265.full.pdf.

[24] Todorova S, Kozhuharova L. Characteristics and antimicrobial activity of Bacillus subtilis strains isolated from soil. World J Microb Biot. 2010;26:1207-1216. DOI: 10.1007/s11274-009-0290-1. 
[25] Hang NTT, Oh SO, Kim GH, Hur JS, Koh YJ. Bacillus subtilis S1-0210 as a biocontrol agent against Botrytis cinerea in strawberries. Plant Pathol J. 2005;21(1):59-63. https://pdfs.semanticscholar.org/6319/e3f619f0a5448add924ceb59d5f5a7d2dfcd.pdf.

[26] Wang JL, Zong ZY, Shang W, Wei QiW, Wang HK. Activity against Botrytis cinerea of Bacillus amyloliquefaciens IMAUB1034 isolated from naturally fermented congee. J Food Agric Environ. 2012;10:534-542.

[27] Wang S, Tongle HU, Yanling J IAO, Jianjian WEI, Keqiang CAO. Isolation and characterization of Bacillus subtilis EB-28, an endophytic bacterium strain displaying biocontrol activity against Botrytis cinerea Pers. Front Agric China. 2009;3(3):247-252. DOI: 10.1007/s11703-009-0042-X.

[28] Ongena M, Jacques P, Touré Y, Destain J, Jabrane A, Thonart P. Involvement of fengycin-type lipopeptides in the multifaceted biocontrol potential of Bacillus subtilis. Appl Microbiol Biot. 2005;69:29-38. DOI: 10.1007/s00253-005-1940-3.

[29] Ongena M, Jourdan E, Adam A, Paquot M, Brans A, Joris B, et al. Surfactin and fengycin lipopeptides of Bacillus subtilis as elicitors of induced systemic resistance in plants. Environ Microbiol. 2007;9:1084-1090. DOI: 10.1111/j.1462-2920.2006.01202.x.

[30] Ongena M, Henry G, Thonart P. The roles of cyclic lipopeptides in the biocontrol activity of Bacillus subtilis. Chapter 5. In: Gisi U, Chet I, Gullino ML. editors. Recent Developments in Management of Plant Diseases, Plant Pathology in the 21st Century 1. Springer Science+Business Media B.V. 2010: 59-69. ISBN 9789400731417. DOI: 10.1007/978-1-4020-8804-9.

[31] Silo-Suh LA, Lethbridge BJ, Raffel SJ, He H, Clardy J, Handelsman J. Biological activities of two fungistatics produced by Bacillus cereus UW85. Appl Environ Microbiol. 1994;60:2023-2030. https://www.ncbi.nlm.nih.gov/pmc/articles/PMC201597/pdf/aem00023-0329.pdf.

[32] Lin TP, Chen CL, Chang LK, Tschen JS. M, Liu ST. Functional and transcriptional analyses of a fengycin synthetase gene, fenC, from Bacillus subtilis. J Bacteriol. 1999;181:5060-5067. https://www.ncbi.nlm.nih.gov/pmc/articles/PMC93996/pdf/jb005060.pdf.

[33] Liu W, Mu W, Zhu B, Du Y, Liu F. Antagonistic activities of volatiles from four strains of Bacillus spp. and Paenibacillus spp. against soil-borne plant pathogens. Agr Sci China. 2008;7:1104-1114. DOI: 10.1016/S1671-2927(08)60153-4.

[34] Mnif I, Ghribi D. Potential of bacterial derived biopesticides in pest management. Crop Prot. 2015;77:52-64. DOI: 10.1016/j.cropro.2015.07.017.

[35] Grata K, Nabrdalik M, Latała A. Evaluation of proteolytic activity of Bacillus mycoides strains. Proc ECOpole. 2010;4:253-256. http://tchie.uni.opole.p1/PECO10_2/PECO_2010_2_p1.pdf.

[36] Nabrdalik M, Grata K, Latała A. Proteolytic activity of Bacillus cereus strains. Proc ECOpole. 2010;4;273-278. http://tchie.uni.opole.p1/PECO10_2/PECO_2010_2_p1.pdf.

[37] Lambertz C, Garvey M, Klinger J, Heesel D, Klose H, Fischer R, et al. Challenges and advances in the heterologous expression of cellulolytic enzymes: A review. Biotechnol Biofuels. 2014;7:135. DOI: 10.1186/s13068-014-0135-5.

[38] Immanuel G, Dhanusha R, Prema P, Palavesam A. Effect of different growth parameters on endoglucanase enzyme activity by bacteria isolated from coir retting effluents of estuarine environment. Int $\mathrm{J}$ Environ Sci Technol. 2006;3(1):25-34. DOI: 10.1007/BF03325904.

[39] Kumar DP, Anupama PD, Singh RK, Thenmozhi R, Nagasathya A, Thajuddin N, et al. Evaluation of extracellular lytic enzymes from indigenous Bacillus isolates. J Microbiol Biotech Res. 2012;2(1):129-137. https://www.interesjournals.org/articles/evaluation-of-extracellular-lytic-enzymes-from-indigenous-bacillusisolates.pdf.

[40] Sethi S, Datta A, Gupta BL, Gupta S. Optimization of cellulase production from bacteria isolated from soil. ISRN Biotechnology. 2013; Article ID 985685. DOI: 10.5402/2013/985685.

[41] Kim YK, Lee SC, Cho YY, Oh H J, Ko YH. Isolation of cellulolytic Bacillus subtilis strains from agricultural environments. ISRN Microbiology. 2012; Article ID 650563. DOI: 10.5402/2012/650563.

[42] Fatema K, Manchur MA. Isolation, identification and cellulase production by Bacillus brevis from the Acacia forest soil. IJRAF. 2015;2:14-22. http://www.ijraf.org/pdf/v2-i9/3.pdf.

[43] Dias P, Ramos K, Padilha I, Araujo D, Santos SFM., Silva FLH. Optimization of cellulase production by Bacillus sp. isolated from sugarcane cultivated soil. Chem Eng Trans. 2014;38:277-282. DOI: 10.3303/CET1438047.

[44] Abbey JA, Percival D, Abbey L, Asiedu SK, Prithiviraj B, Schilder A. Biofungicides as alternative to synthetic fungicide control of grey mould (Botrytis cinerea) - prospects and challenges. Biocontrol Sci Technol. 2019;29(3):207-228. DOI: 10.1080/09583157.2018.1548574.

[45] Bakkali F, Averbeck S, Averbeck D, Idaomar M. Biological effects of essential oils - A review. Food Chem Toxicol. 2008;46:446-475. DOI: 10.1016/j.fct.2007.09.106. 
[46] Mohammadi P, Lotfi N, Naseri L, Etebarian HR.. Antifungal activities of essential oils from some Iranian medicinal plants against various postharvest moulds. J Med Plants Res. 2013;7(23):1699-1708. DOI: 10.5897/JMPR11.1518.

[47] Felšöciová S, Kačániová M, Horská E, Vukovic N, Hleba L, Petrová J, et al. Antifungal activity of essential oils against selected terverticillate penicillia. Ann Agr Env Med. 2015;22(1):38-42. DOI: $10.5604 / 12321966.1141367$.

[48] Lopez-Reyes JG, Spadaro D, Gullinoa ML, Garibaldia A. Efficacy of plant essential oils on postharvest control of rot caused by fungi on four cultivars of apples in vivoi. Flavour Frag J. 2010;25:171-177. DOI: 10.1002/ffj.1989.

[49] Wójcik-Stopczyńska B, Jakowienko P, Wysocka G. The estimation of antifungal activity of essential oil and hydrosol obtained from wrinkled-leaf mint (Mentha crispa L.). Herba Pol. 2012;58:5-15. http://www.herbapolonica.pl/app/webroot/magazines-files/7494275-W\%C3\%B3jcikStopczy\%C5\%84ska\%20et\%20al.pdf.

[50] Ekor M. The growing use of herbal medicines: issues relating to adverse reactions and challenges in monitoring safety. Front Pharmacor. 2014;4:1-10. DOI: 10.3389/fphar.2013.00177.

[51] Kamatou GPP, Vermaak I, Viljoen AM, Lawrence BM. Menthol: A simple monoterpene with remarkable biological properties. Phytochemistry. 2013;96:15-25. DOI: 10.1016/j.phytochem.2013.08.005.

[52] Kizil S, Hasimi N, Tolan V, Kilinc E. Mineral content, essential oil components and biological activity of two mentha species (M. piperita L., M. spicata L.). Turk J Field Crops. 2010;2:148-153. https://pdfs.semanticscholar.org/b101/26563e4d0f5e8f168750f165dfaa56c3926f.pdf.

[53] Soković MD, Vukojević J, Marin PD, Brkić DD, Vajs V, Griensven LJL. Chemical composition of essential oils of Thymus and Mentha species and their antifungal activities. Molecules. 2009;14:238-249. DOI: 10.3390/molecules14010238.

[54] Edris AE, Farrag ES. Antifungal activity of peppermint and sweet basil essential oils and their major aroma constituents on some plant pathogenic fungi from the vapor phase. Nahrung/Food. 2003;7:117-121. DOI: 10.1002/food.200390021. 